\title{
An Investigation on the Subject Matter of Tambaro Proverbs
}

\author{
Handebo Hankore Harsana ${ }^{1}$, Tsegaye Abie Gebeyehu ${ }^{2, *}$ \\ ${ }^{1}$ Department of English Language and Literature, College of Social Science and Humanities, Kebri Dehar University, Kebri Dehar, \\ Ethiopia. \\ ${ }^{2}$ Department of English Language and Literature, College of Social Science and Humanities, Wachemo University, Hossana, Ethi- \\ opia.
}

How to cite this paper: Handebo Hankore Harsana, Tsegaye Abie Gebeyehu. (2020) An Investigation on the Subject Matter of Tambaro Proverbs. Journal of Humanities, Arts and Social Science, 4(2), 149-158. DOI: 10.26855/jhass.2020.07.009

Received: September 17, 2020

Accepted: October 20, 2020

Published: November 18, 2020

${ }^{*}$ Corresponding author: Tsegaye Abie Gebeyehu, Assistant Professor, Department of English Language and Literature, College of Social Science and Humanities, Wachemo University, Hossana, Ethiopia.

Email: tsegayeabie@gmail.com

\begin{abstract}
The main purpose of this study was to analyze overriding themes of Tambaro proverbs. Data were collected through interview, focus group discussion and observation. Snowball sampling and purposive sampling techniques were employed. Collected proverbs were translated from source language (Tambarissa) to target language (English) through communicative approaches, categorized and analyzed according to their themes which are portrayed through proverbs of Tambaro. The analysis was carried out through the descriptive method following the qualitative design. Accordingly, it was identified that, conflict resolution and Molliyae (LemallaMolla meetings) are found to be the most important social contexts where in the proverbs are dominantly used where senior people or elders of the society come together and perform proverbs while resolving conflicts. The findings of the study shows that basic themes Tambaro proverbs are the roles of elders, ways of managing some social disputes, way of resisting economic difficulty, issue of identity and cooperation. Based on the results of the study that further researches need to be conducted to document and preserve the proverbs.
\end{abstract}

\section{Keywords}

Proverbs, Subject matter, Tambaro, Language

\section{Introduction}

All human societies have their own custom, norms, values, beliefs and oral tradition. Those human societies reflect their own identities through speaking or writing. According to Simiyu (1994: 96), Africa today is considered as an oral society because the bulk of its tradition and literature are still oral. Fekade (1991) defines folklore as an accepted heritage that links life manner, philosophy and general attitude of one generation to the next generation. It offers the new generation with cultural, political, economic and social life of the past generation. There are different forms of folklore in general oral literature that serves the stated purposes. Dorson (1972), on the other hand, puts folklore under four categories. These include verbal arts such as myths, legends, folktales, riddles, oral poetry and etc., material culture, performing folk arts, and social folk custom. The current study focuses on proverbs which lie on verbal generic classification of folklore.

Moreover, Simiyu (1994) indicates that oral literature serves as a means by which unlettered people give artistic expression to their deepest thoughts and feelings. Hence, it is possible to say that oral literature reflects the people's life manner. Through folklore one can express truth, wisdom, philosophy of the societies, traditional value and morality. For example, Dagnew and Wodajo (2014) indicate that proverbs are a form of oral literature that contains 
concise expression with universal truth, wisdom, social reality, and philosophy of the society and socio-cultural situation of the people. This shows that one can understand socio-cultural reality of certain community through study of oral literature. Proverbs are a form of oral literature or verbal art that is used in different occasions in the context of day to day conversation. They present traditional wisdom of the society that observed from long life experience.

According to Kohistani (2011: 17), cultural concepts deal with mental structures, which enable an individual to save perceptual and conceptual information of his or her culture, as well as to interpret cultural experience and expression. This indicates that people provided with aids to interpret cultural phenomena of the society. According to Kohistani (2011: 11), one major reason why proverbs are observed and studied even nowadays has to do with the phenomena that proverbs convey different cultural pictures. Since proverbs contain observation of everyday life, they represent popular philosophy of life and provide an insight into human behavior and character. They can also be used to transmit knowledge of the culture of the given society. It can be said that proverbs show socio-cultural situation of a given group of the people.

According to Zerihun (2010: 22), the origin of Tambaro people is Sidama, specifically Yemerera. The seven sons of Molla migrated from Yemerara to Tambaro land. When the seven brothers (LamalaMolla) left the yemerera land they passed several areas by sowing white sorghum (Yelelo, in Tambarissa) to test for settlement. Finally, they settled in Tambaro land meaning we have settled. Now the LamalaMolla group called Tambaro. The LamalaMolla group of Tambaro includes Yaaga, Adde, Waaja, Quna, Taase, Ajora and Sanbata. According to Tambaro oral tradition, the members of the group cannot marry each other from ancestor time up to the present day.

According HandeboHankore (2020), Tambaro is one of ethnic groups in Ethiopia located in South Nation Nationalities and Peoples Region (SNNPR) in Kambata Tambaro zone specifically in Tambaro district. The language spoken in Tambaro is Tambarissa. Like any other Ethiopian languages, Tambarissa Language is rich in its oral literature in different forms like folktales, songs, proverbs and so on. But proverbs are frequently used in Tambaro society. Tambaro people use proverbs in their day to day speech occasion regarding different contexts.

As Handebo stated Tambaro proverbs are used in different social circumstances like coffee ceremony, funeral ceremony, wedding ceremony, true Cross festival. Tambaro elders use proverbs to reflect their past socio-cultural truth, wisdom, reality of the people. This article focusing on overriding issues of Tambaro proverbs

\subsection{Statement of the problem}

According to Chesaina (1994: 84), oral literature is "The heart of a people's way of life; it is the soul of their culture. It expresses a given society's world view and gives them a spring-board from which their day-to-day existence is forwarded". As she stated oral literature preserves people's traditional culture which plays a significant role in the development of modern culture in modern context. Proverbs are forms of oral literature that reflect wisdom, and philosophy of the people. This cultural heritage could be studied in every ethnic group. Handebo H. (2020) has made an attempt to see corrective functions of Tambaro proverbs but he didn't see subject matters of Tambaro proverbs. According to the knowledge of the researchers, it seems that no another attempt has been made so far to collect and analyze the proverbs of Tambaro. Due to this reason, the researchers are motivated to conduct this study on thematic analysis of Tambaro proverbs.

\subsection{Objectives of the Study}

\subsubsection{General objective of the study}

The main objective of this study was to collect, analyze and interpret the overriding themes of Tambaro proverbs.

\subsubsection{Specific objectives of the study}

The specific objectives of the study include:

$>$ To investigate themes revealed in Tambaro proverbs

$>$ To preserve Tambaro proverbs.

\subsection{Scope of the study}

This study basically focused on analyzing Tambaro proverbs particularly on its thematic analysis. This is because it is very difficult to inculcate all features of proverbs in this single study. 


\section{Chapter Two: Review of Related Literature}

\subsection{Folklore}

\subsubsection{Concept of Folklore}

Folklore can be said a means in which people use certain activities to show traditional way of life in certain group of the people who share something in common. The traditional ways of life may include customs, norms, beliefs, politics, rituals, marriage, burials, wearing style, and so on. It could be shown through oral poetry, songs, dances, proverbs, jokes, parables, folktales, riddle, myths, and etc.

Dundes (1965: 2) explains that the folk refers to the group of the people who shares something in common. It may be culture, occupation, language, religion, and etc. So folklore can be said the lore of the people or the traditional knowledge of the people.

It can be said folklore deals with wide aspects of human society. It can be understood as custom, tradition, belief, values, and whatever aspect of ways life in the past expressed through folklore.

This helps to connect socio-cultural, economic, and over all life philosophy of the past generation to the present generation through oral heritage. It could be said that folklore is the bridge between the past and the present people's life manner.

In general Dorson (1972) attempts to define folklore by classifying it in to four categories: oral literature or verbal art that includes proverbs, folktales, oral poetry, riddles, myths, and etc; material culture which consists traditional materials like construction of home, clothe making, design of furniture, and etc; performing art such as traditional dance, drama and songs; and social folk customs that include traditional belief, marriage, funeral, and etc. The current study focuses on oral literature specifically proverbs.

\subsubsection{Theories of folklore}

Folklore in general oral literature could be studied from different dimensions. It may be seen from stylistically, functionally, structurally, anthropologically, contextually, and etc.

According to Dorson (1972: 6-48), there are twelve theories of folklore studies such historical-geographical, historical-reconstructional, ideological, psychological, functional, structural, oral-formulaic, cross-cultural, folk-cultural, mass cultural, hemispheric, and contextual theories of folklore studies. As indicated in the title of this study the researcher uses functional theory for his study among others approach. Functional approach of folklore deals with the socio- cultural significance of folklore in general and proverbs in particular.

As Dorson (1972) stated one of persuasive to folklore studies is the functional approach of folklore deals with how folklore serve certain function or significances of verbal arts in a given society.

Okpewho (1992), puts functionalism emerged as a method of studying the life and culture of the society by examining the roles or functions performed by anything practiced in the society as well as the way in which these functions help to ensure the survival of the society.

As he asserted functionalist studies of folklore in general oral literature in particular useful in discovering the various ways in which literature reflects the way of life, the outlooks, and interests of the society that practice it.

According to Ben Amos (1982: 46), functional approach to folklore deals the relationship between forms of oral art and existing social, cultural, political, and psychological needs.

According this functionalist theory folklores are used to know the culture of certain ethnic group who shares something in common. In short as Finnegan (2012) suggested functional approach helps the researchers to explain why the study of oral literature in general proverbs in particular has made.

However, the function of folklore could be understood through the knowledge of the context in which it is performed. For example, a single proverb may have different meaning according to socio-cultural context in which the proverb is used.

This shows that functional approach of folklore related with contextual theory of folklore studies. Dorson (1972) discusses that one should identify the social setting to examine vital role played by the forms of folklore. Thus, the researcher of this study uses functional approach of folklore in general and proverbs in particular to identify the themes of Tambaro proverbs and the context in which they are used.

\subsubsection{The Function of Folklore}

Folklore plays a significant role in studying the society's ways of life. According to Bascon (1965: 277), the function of folklore stated as follow:

"Some of the most essential functions of folklore include aiding in education of the young, promoting a group's 
feeling of solidarity, providing socially sanctioned ways for individuals, serving as a vehicle for social protest, offering an enjoyable escape from reality and converting dual work in to play”.

The above quotation shows that folklore plays a crucial role in educating the young generation of a given society about society's manner of life, encouraging doing something which appropriate to the society's norm and discouraging something deviated from the society's culture.

According to Fekade (1991), folklore is a popular heritage that bridges the life style, philosophy and attitude of a generation to next generation. In other words, folklore present generation gets access to learning the social, cultural, political and economic lives of the past generation from the existing folkloric forms. It is possible to say that the available forms of folklore can help someone to observe people across generations.

They preserve the past traditions, customs and philosophical views across generations. It provides some knowledge about what people experienced from the past to the present one. It is possible to say folklore connect culture of the previous generation with the new one.

According to Dundes (1992: 26), folklore plays a vital role to sanction and validate religious, cultural, social and economic institutions, and it serves as an educative device in their transmission of culture of the society from one generation to another. This shows that folklores have a pedagogical role to instruct the people's life manner of one generation to the other generation.

In one way or in other way folklore in general and oral literature in particular is a means of instructing or teaching people's life status and cultural values of the past in a given society. In conclusion folklore served as a means for presentation of cultural, social, political, economic and traditional practices of the society. Proverbs as a part of folklore in general oral literature in particular serve similar functions.

\subsubsection{Forms of Folklore}

According to Dorson (1972) and Fekade (1991), folklore can be classified under four broad categories; these are material culture, social folk custom, performing folk arts and oral literature or verbal arts. Material culture can be defined as one of the form of folklore that encompasses visible cultural materials. As Dorson stated material or physical folk life presents something visible that transmitted across the generations. It may include design of constructions, folk craft, clothes (folk costume), preparation of food (folk cookery), and etc. Social folk custom is one of generic classification of folklore that highly focuses on public practices.

Fekade (1991) and Dorson (1972) assert that it emphasizes group's interaction rather than private skills and performances. It includes items like landmarks, manors, folk festivals, folk religion, birth rituals, marriage, initiation, and funeral and so on. Performing folk arts is another form of folklore that refers to traditional folksong or music, dance and drama.

According to Dorson (1972), this generic classification of folklore emphasizes on actual performance by individual or groups with folk instruments, drama and dance costume, and scenario props. The fourth and the last classification of folklore is oral literature or verbal art. As its name suggests is verbal heritage of the society that is transmitted from generation to generation by word of mouth. Dorson defines oral literature as traditional utterance in the forms of spoken, sung and voiced that show repetitive patterns. It includes folktales, myths, legends, songs, riddles, charms, proverbs, oral poetry, and etc. In short, it can be understood as traditional verbal compositions of the society.

\subsection{Oral literature or verbal art}

Oral literature can be defined as a verbal heritage of human society that transmitted from generation to generation by word of mouth. Okpewho (1992) and Murphy (1978) define oral literature as an utterance that whether spoken, sung or recited, whose composition and performance enjoy to the artistic characteristics of accurate observation of the society. It includes folktales, riddles, proverbs, puns, songs, legends, myths, chants, and etc.

It can be deduced oral literature deals with verbal arts of arts of the given society, and those verbal arts have their own characteristics.

According to Finnegan (2012), actual performance is one of characteristic feature of oral literature. As she stated oral literature depends on performer who formulates specific socio-cultural contexts. This expression can be understood as oral literature can be verbal formulations of performer in certain social context. Another characteristic feature of oral literature is its means of transmission from generations to generations.

Fekade (1991) and Okpewho (1972) stated that oral literature is cultural heritage that transmitted by words of mouth. In short, oral literature is a form folklore that transmits from generation to generations through spoken words; it can be understood specific socio-cultural contexts. Regarding to its functions, oral literature serves very important 
roles in a given society.

According to Okpewho (1972), entertainment is one of vital role of oral literature. It entertains the people who are bored in certain uncomfortable situation. As he suggested stories are one form of oral literature that entertains the audiences. In addition to its entertainment values, oral literature helps the people to explain the nature of the universe the live in. He asserts that oral literature reflects people's life manner, norms, values, socio-cultural situation and socio-economic situations which are observed from the past. Proverbs share the characteristics, and serve similar functions of oral literature. As form of oral literature, proverbs can be interpreted based on the context in which they are formulated by performer. This can be said the functions of proverbs understood from the socio-cultural environments in which they are performed.

\subsection{Proverbs}

Proverbs are one of oral literature that touches general truth in this real world. They are very short statements that are used day to day conversation of the people.

According to Mieder (1996), proverbs are concise traditional statements of apparent truths with currency among the folk. More elaborately stated, proverbs are short, generally known sentences of the folk that contain wisdom, truths, morals, and traditional views in a metaphorical, fixed, and memorisable form and that are handed down from generation to generation.

Ted Hildebrant (2005) defines proverbs as a short, general known sentence of the folk which contains wisdom, truth, moral, traditional views in metaphorical, fixed and memorable form which handed down from generation to generation. It can be deduced that proverbs are very short, concise, special, memorable, and metaphorical expressions which are used in day-to- day speech occasions in order to reflect norms of certain society.

\section{Research Methodology}

In this article, qualitative research approach is employed. The researcher conducted interview with some selected elders of Tambaro society who are selected through snowball sampling technique, 23 proverbs were selected through purposive sampling observed some important some social contexts in which proverbs of the society are performed, and conducted focus group discussion three times with six elders from five kebels.

At the end, the collected proverbs from the source were analyzed through qualitative method of data analysis.

\subsection{Subject matter of Tambaro proverbs}

In this sub-section, proverbs of Tambaro are interpreted based on the subjects or overriding issues portrayed through them. Proverbs are categorized and analyzed based on elders, co-operation, poverty, identity and conflict. In these themes some sample proverbs where collected, and analyzed in the following.

\subsubsection{Proverbs on elders}

In Tambaro society, elders are supposed as a knowledgeable people in the society, and they are respected individuals in the society.

\section{(1) Nubabu soresa}

\section{(Elders are the heritage)}

Informants asserted that elders shoulder a lot of responsibilities in transmitting their long life observations for new generation. That means they are a means to connect the philosophies of the past generation with the generation. In the above proverb, the word heritage symbolizes the roles of elders. Heritage is very important to show what people experienced in the past. In the context of this proverb, similarly, elders reflect socio-cultural practices of the society observed from the past. This proverb shows that elders can teach the young generation regarding to norms of the society, social and economic status of the society. The above proverb also portrays elders as sources of popular customary practices of Tambaro society. This proverb encourages approaching elders to learn or to know socio-cultural realities of the society.

One of informants in the focus group discussion asserted the following two proverbs which are indicate elders as documented materials those hold certain knowledge regarding to something.

\section{(2) Nubabu eri wogi tolancho}

(Elders are a bridge of the society's culture)

(3) Nubabu mato wogi mexafa

(Elders are the book of culture)

In the proverb the word "bridge" elders connects the previous generation's life status with the present day gener- 
ation. Bridge is used to cross river or lake from one side to the other side. In the context of the above proverb it is metaphor for the mediating roles of elders between the old generation and the new one. This proverb shows that elders are knowledgeable people who link the life philosophies of the past generation with the new generation. In the second proverb elderly people compared the book that is written for culture of certain society in order to show the stored knowledge senior people regarding to culture of the certain society. This reveals elders have a lesson to teach the youth regarding to customary practices of the society from their life observations.

\section{(4) Nubabu eriha mumita}

(Elders are the head of the society)

In Tambaro society, elders are responsible in solving whatever social disorder in the society. According to informants, elders are very responsible resolving disputes, advising, teaching, encouraging and discouraging for their actions. In the above proverbs the word "head" is the symbol the central role served by elders in Tambaro society. This proverb portrays that elders engaged every social issues, and they are responsible those issues. Mr. Chemiso Wachemo (one of interviewee) asserted that elders have something to transfer to the generation, and he forwards the following proverb in his speech.

(5) Haqucho amet hagelotanse matura higisa nubachu qalenche

(A stem has something for its branches and an elder has something for generation)

In this proverb, the roles of elders for generation compared the roles stem for it branches in order to show the responsibilities of elders in the Tambaro society. In this context, stem holds its branches, and it observes minerals and water from the earth by its root and transmits those minerals and water to its branches. In the context of this proverb, similarly, elders transmit manners of life those experienced during their life existence for young generation. This proverb shows elders have knowledge of the society's culture to teach the new generation. The above proverbs also show elders have socio-cultural knowledge the practiced in the society. This helps the new generation to know socio-cultural back ground of the society.

\section{(6) Nubabu xewan anjenata worit hoqa}

\section{(Elders resolve dispute by adding spices in their speech)}

This proverbs alludes an attractive expressions uttered by elderly people. It shows elders play crucial roles in settling disputes among households and members of the society. In the above proverb, the word "spices" symbolizes very interesting expressions used by senior people. In the proverb, spices and attractive expression from elderly people in order to show elders use interesting words or statements in their speech occasions in order to catch the attention the listeners to the points. In short, the above proverb shows that elders of Tambaro play significant roles in conflict management, and they are wise in using expressions in the speech occasions.

\subsubsection{Proverbs on identity}

Tambaro proverbs are used to encourage young generation to have awareness on cultural, social, political and economic status of the society. The proverbs of the society motivate individual to know popular customary practices of the society.

\section{(7) Qoxita aqinami yenanen qoriti uba}

(He who intends to take others resources misses his own)

In Tambaro society, elder people suppose that young generation of the society may going to somewhere and observe socio- cultural practices of that society, and forget his or her own cultural practices. Mr. Lelago Lemore (one of informants) explains that the current generation influenced by modernization, and going to lose the knowledge of cultural practices of Tambaro society. In the above proverb, the phrase "others resources" signifies the socio-cultural practices of other society, and the phrase “one's own resources” refers to one's own society's customs, norms, believe systems, political and economic status. In the context of this proverb the word "resources" refer to customary practices in the society. This proverb talks about the knowledge of one's own cultural resource is the baseline for knowing the cultural resource of other societies. In this context the proverb, elderly people use this proverb to encourage the young generation to have knowledge on popular customary practices of Tambaro society.

\section{(8) Woloba degubuhu marenoba deganoba}

(He who didn't know from where he comes he will not know where he will go)

Proverb of Tambaro used to encourage individuals to have an ability to know one's own society's customs, norms, and socio-cultural practices. As interviewee asserted the knowledge one's own culture helps to know the culture of others. This shows if somebody does not know cultural practices of his society he will not know the culture the others society. In the above proverb the phrase 'from where he comes' shows the individual's culture, and the phrase "where 
he will go" refer to the culture of others. The above proverb encourages young generation to have knowledge on his or society's culture. In other words, this proverb is used to encourage the youth to know the society's history, culture, identity and norms. Through this proverb elder of Tambaro the knowledge of one's one identity helps to know the identity of others.

(9) Zegish mechati zehi zehi azentas ubano

(The leaves of yellow wood fail under it)

Young generations of Tambaro society went to different parts of Ethiopia due to different reasons. One of the informants explained that wherever people go they will turns back to their society. He asserted the above proverb in his speech. In the above proverb the word "yellow wood" is a big tree that has many branches next Dagale tree. In the winter season, Tambaro people sit under its shadow. In the context of the above proverb, it signifies one's own country or society, and the leaves of the yellow wood symbolizes the youths in Tambaro society. The failing leaves under the yellow wood shows wherever individuals go they the turn to the society.

So the above proverbs encourages the people to have knowledge on one's own society's norms, social rules, regulations, religions, social, cultural and economic situations. In other words, the above proverb motivates to know one's own identity.

(10) Mini gochini agubuhu mogeancho

(He who is not enter home on door is thief)

(11) Menu minchi hadan heanoba

(People can't live outside their home)

People live according to the rules and regulations of their society. They can't live outside the norms of the society. In the above two proverbs, the term "home" represents the norms of Tambaro society (one's own identity). In the first proverb, the word "door" refers following the norms the society, and the word thief represents an individual who follows something that deviated from the norms of Tambaro society.

The second proverb shows that difficulty of living outside of the home which stands for the members of Tambaro society should live according the norms of the society. The above two proverbs are used to encourage the people according to the principle that followed in Tambaro society.

\subsubsection{Proverbs on cooperation}

Proverbs of Tambaro are used to portray the significances of close relationship among members of Tambaro society. This concept is portrayed in the following proverbs.

\section{(12) Mexi zurumichut mexura hujetaba}

(Nothing can be done through a single finger)

In Tambaro society, senior people encourage mutual support among the members of Tambaro society. They suppose a person alone cannot be successful in certain intended objective. They use proverbs in order to advise the young generation to support each other. In the above proverb, the word "finger" represents individual alone. The proverbs shows people need cooperation with others in order to be successful in certain intended aims. Elderly people in Tambaro society use the proverb to strength collaboration among the people in Tambaro society. In other words, this proverbs encourages young generation sharing something, and to work cooperatively.

(13) Betinashu tue yi gan winshanu

(Saliva from many people can be filled in the tank)

In Tambaro society, proverbs show support from many people can solve whatever social problems. According to the interviewee elders of Tambaro use proverbs to strength unity among the members of the society. In the above proverb, the term 'saliva' signifies a little support from a group of the people, and the word 'tank' represents a difficult problem that somebody faced. This proverb alludes that whatever difficulties can be solved through cooperation among the people around us. Senior people of Tambaro society use this proverb to strength friendship among individuals in Tambaro.

\section{(14) Mexoman biratu bixamano}

(Within friendship iron can be broken)

This proverb shows friendship or cooperation helps to solve certain difficulties that somebody faced in his/her life. In the above proverb, the word "iron" is very strong metal that cannot easily break. In the context of this proverb it is metaphor for very difficult situations that cannot be solved by individual alone. The proverb shows cooperation plays central roles in solving certain social difficulties. Through this proverb elders of Tambaro people encourage the youth to cooperate each other in the society. They also show the significances of close relationship with other people. Tambaro proverbs teach the youths with whom they should have friendship. This portrayed in the following proverb. 


\section{(15) Holichon hoso felechut meshima rosa}

(A goat that spends with sheep can learn humbleness)

In Tambaro society, people herd goats and sheep. In the above proverb, the behavior of sheep portrayed as humble in order to represent the individuals have well accept personality in the society, and the word "goat" signifies the individuals who have deviated behavior in the society. The above proverb shows that the people who have good behavior can change the attitude of people with deviated behavior, and they can bring them to their characters. The meaning of this proverb is good friend teach socially accepted behavior for the others. Social function of the proverb is encouraging individuals to make friendship with individuals who have socially accepted individuality in the society.

\subsubsection{Proverbs on conflict resolution}

In Tambaro society, proverbs are used to portray negative influence of disputes, conflict resolution methods and catching the attentions of opponents in conflict resolution.

\section{(16) Beanchat leinu kentia}

(Disputes affect the development of the society)

Elders of Tambaro society use proverbs in order to reveal demerits of conflict, and to strength peaceful existence in Tambaro society. The above proverb shows the negative impacts of dispute among households, members of family and the society. This proverb is used to encourage the young generations to have close relation with people around them.

\section{(17) Hoqata meganu eteno beanchata shexanu eteno}

(God likes conflict resolution evil likes disputes)

In Tambaro society, conflict resolution is one popular social context in which elders settle disputes. According to informants use proverbs in order to catch the attention of opponents. They criticize the individual who is not interested in conflict settlement in Tambaro society. In the above proverb shows the individual who refuses conflict resolution is portrayed as an evil. This proverb indicates Tambaro people suppose that dispute is the act of evil spirit, and peaceful coexistence is the character of God and He likes peaceful life of the people. This proverb is used to encourage young generation to be interested in conflict resolution in the society. The above proverb is also used to catch the attention of opponents in conflict resolution.

(18) Alen etun godabu eteno gar meganu eteno

(Stomach likes eating in clean hand and God likes speaking truth)

In Tambaro society, elderly people use proverbs in conflict resolution in order to encourage the opponents to tell the real case of dispute between them. In the above proverb the phrase "eating through clean hand" refers to living peacefully. This proverb is used to get the attention of the opponents and to settle the dispute easily. The proverb also used to encourage the people to speak truth.

\section{(19) Mosi zebu kinina beancha zebu hoqata}

(Drug is treatment for disease and conflict resolution is treatment for dispute)

In the above proverb, drug is compared with conflict resolution and disease compared with having dispute with somebody in order show the importance of conflict resolution and the negative impacts of having dispute. The above proverb shows that conflict resolution is a means of peaceful existence in the society. In the above proverb the word drug signifies peaceful coexistence. This proverb is used to encourage the people to live in harmony

(20) Gambala holichin wajo wolichin gofubu beanchat yoba

(There is no any dispute that cannot be resolved settled by black and white sheep)

According to interviewee Guda process is difficult procedure in which dispute happened by killing life. In guda, the killer of somebody buys black and white sheep, and come up with sheep in the day of conflict settlement. He slaughters the black sheep in near to river which shows the killer agreed to not kill the people again and wrongness of the killer, and he and his family turns to his home by lead the deed's family and the elders. In the killer's home elder of the killer family slaughter the white sheep which shows peaceful existence in the future. Finally, the families sit together and eat the prepared ceremony, and the elder bless them to live together in the society. The above proverb indicates that whatever disputes can be settled. In the above proverb white sheep and black sheep refers dispute that happened difficult cases.

(21) Abee xawe qewu asenuhu woya qewu xawe abee aseno anichii

(Making difficult thing to easy is better than making easy thing to difficult)

This proverb is used in conflict resolution between two brothers on April 13, 2009. During the time, one of the 
opponents is not want resolution of the dispute within the society's elders. This proverb is uttered when somebody refused to accept what elders said in certain disputes and exaggerated the case of the dispute. In this conflict resolution the mediator used the above proverb in order to change the mind of the opponent party regarding to their disputes and to create close relationship between the opponents. The above proverb is used to discourage refusing the idea of elders of Tambaro society, and to encourage the people to see easily the cases of certain dispute.

\subsubsection{Proverbs on poverty}

In Tambro society, proverbs are used to portray poverty. This expressed in the following proverbs.

\section{(22) Buxiche jalu yoba}

(A poor has no friends)

This proverb shows that people don't want to cooperate with hunger individual. In the context of the above proverb, "friend" represents supporters. In other words, poor people have no supporters. The elderly people of Tambaro society use this proverb to encourage the young generation to help poor people in the society. This proverb also encourages the youths collaborate with people who live in certain economic difficulties. The elders use the proverb to advise the people to support poor people who live with economic problem.

\section{(23) Menu mumi usureda yemechu mechat usurano}

(When human beings entertained by their hair and rate entertained by its ear)

Human beings have hair, and it is considered as beauty of them, and the rate has ear but it has no hair. In the context of the proverb, human beings with hair refers the people who live standard economy, and rate with ear represents people at low economic status. The main theme of this is living according to one's on economic situations. This proverb encourages people to live according to their economic status.

\section{(24) Megabitu megari mini agisano}

(On March people enter the home of individuals who have disputes with them)

According to the interviewee, in Tambaro area, March is very warm month, and most people faced economic problems on March. In the above proverb "people enter the home of individuals who have dispute with them" shows very difficult economic situation in Tambaro society.

\section{Conclusions and Recommendations}

\subsection{Conclusions}

The main objective of this study was to analyze contextual functions of Tambaro proverbs. In Tambaro society, different forms of oral literature are used in the speech occasions like conflict resolution and lemallamolla meeting. Tambaro proverbs help the new generation to distinguish well-accepted customary practices in the society and the practices that deviated from the culture of Tambaro. For instance, Tambaro proverbs are used to teach the young generation about co-operation, faithfulness, loves, friendship, the habit of respecting elders, the advantages of sharing idea, and etc. Some major themes revealed through proverbs of Tambaro are cooperation, conflict resolution, identity, and poverty.

In short, Tambaro proverbs are performed in any speech occasions in order to produce well individuals in the norms of Tambaro society.

\subsection{Recommendations}

The researcher has made an attempt to analyze the basic themes of Tambaro proverbs. However, this study is not enough to show the roles of all forms of oral literature in general, and proverbs of Tambaro society in particular. So, the researcher highly recommends others to conduct further study on other forms of oral literature in general and proverbs in particular in order to show social relevancies of Tambaro oral literature in general and proverbs in particular because Tambaro oral literature in general and proverbs are not exhaustively studied. In short, the researcher of this forwards the following suggestions:

$>$ Tambaro oral literature in general and proverbs in particular should be documented.

$>$ Other researchers could conduct further research on different forms of oral literature of the society.

\section{References}

Bascom, W. (1965). Function of folklore. Dundes. Study of folklore. Englewood Cliff: Printice Hall Inc.

Ben-Amos, D. (1982). Folklore in context. Daryagani: New Delhi. 
Chesaina, C. (1994). Image of women in African oral literature: A case study of Kalenjin and Maassai oral narrative. Bukenya, A and et al. (Ed). Understanding Oral literature. Nairobi: Nairobi University Press.

Dorson, R. (1972). Folklore and folklife: An introduction. Chicago: The University of Chicago

Dundes, R. (1965). The study of folklore. Englewood Cliff: Prince Hall Inc.

Fekade Azeze. (1991). Introduction to oral literature. Addis Ababa.

Fekade Azeze. (2001). The State of Oral Literature Research in Ethiopia: Retrospect and Prospect. Journal of Ethiopian Studies. Vol. 34, No. 1. Pp. 43-85.

Finnegan, R. (2012). Oral literature in Africa. Oxford University Press.

Halima, A. (2005). Thematic analysis of some selected Hausa proverbs. Sokoto: Nigeria.

Handebo, H. (2020). Corrective Functions of Tambaro proverbs. Kebri Dehar, Ethiopia: Research Humanities and social science, Vol. 10, No. 13, 2020

Hildebrandt, T. (2005). The Proverbs: an interdisciplinary approach to biblical genre. Gordon University: Wenham.

Kohistani, Z. (2011). Understanding Culture Through Proverbs English vs Dar. British.

Mieder, W. (2004). Definition and Classification. In. Proverbs: a handbook. London: Greenwood Press.

Okpewho, I. (1992). African Oral literature. Bloomington: Indian University Press.

Simiyu, V. (1994). Oral literature as part of oral traditions. In Bukenya, A and et al. (ed). Understanding Oral Literature. Nairobi: Nairobi University Press.

Tesfaye Dagnew and Mesfin Wodajo. (2014). The socio- cultural function of Kafa proverbs. African journal of history and culture, v6/6, pp. 94-99.

Zerihun Doda. (2010). Ethno-history of Tambaro nationality. Hawassa: Hawassa University. 